\title{
Product Innovation, Strategy and Exporting Performance: a Study in a Candy Confectionary Company
}

\author{
Marco Antonio Leandro Cabral ${ }^{a}$, Hélio Roberto Hékis ${ }^{a, b}$, Lara Cavalcante Freitas da Silva ${ }^{a}$, \\ Lawrence Cézar Medeiros Araujo de Moura a , Maíra Luciano Sidrima,c \\ Universidade Federal do Rio Grande do Norte - UFRN \\ bUniversidade Federal de Santa Catarina - UFSC \\ Faculdade Boa Viagem - FBV \\ e-mails: mcabral2014@gmail.com; hekis1963@gmail.com; larafreitas2@hotmail.com; lawrencemedeiros89@gmail.com; mairaluciano@hotmail.com
}

\begin{abstract}
The Brazilian companies have crossed geographic borders, commercially and also culturally in search of longevity for their products and services. This study aimed to evaluate the impact of the strategic factors and the product innovation on the exporting performance in a candy confectionary company. In this regard, it has been analyzed the internationalization strategies used by the company, through quantitative and qualitative methods by application of a survey and interviews which, together, enabled to compare the importance and the performance of various attributes considered decisive to the exporting performance. Among the achieved results, this work showed there is a gap between the degrees of performance versus the degrees of importance of the studied attributes. This means that, by top management perspective, the company is below market expectation. It evidences the necessity for reevaluation the strategic planning, in order to strength other important dimensions explored, aiming to achieve success in the international market. This study confirmed the existence of a strong relationship between innovation product, strategy and exporting performance.
\end{abstract}

Keywords: strategy, exporting performance, innovation product, internationalization.

\section{Introduction}

Due to the current economic situation, most companies face the need to innovate as a survival demand and the recognition of this necessity of innovation, as well as the difficulty to stimulate and promote a sustainable innovative environment, drives to the raise of a mini industry of consultancy and research in management, focusing on this area of knowledge. Therefore, product, process and management innovation are becoming more relevant for international business scenario every year.

The gradual internationalization model developed by Johanson and Vahlne (1977), known as the Uppsala Model, served as the basis for a significant part of international business research in the twentieth century, however, is not enough to explain the current processes of internationalization. This research points at other important success factors in internationalization strategy, such as: insertion in relationship networks, entrepreneurship, product and process innovation (JOHANSON; VAHLNE, 2009, 2011; KNIGHT; CAVUSGIL, 2004; MATHEWS; ZANDER, 2007; MOEN; GAVLEN; ENDRESEN, 2004; WEERAWARDENA et al., 2007).
Concerning to this problematic, the main objective of this study is to evaluate the impact of strategic factors and innovation over the exporting performance in a food company in the candy confectionary sector. The specific objectives are to compare the degrees of importance and performance of critical success factors in internationalization, according to the organization's top management executives perspective and perform a quantitative analysis of the scenario in which the company is inserted.

Next session will show the key concepts of strategic factors, innovation and exporting performance. Then, the methods of this study will be shown. The results will be presented and simultaneously discussed afterwards, and lastly, the session containing the conclusions.

\section{Innovation, strategy and exporting performance}

Kim and Mauborgne (2005) analyzed high-growth US companies over a 120-year period and found that, over time, high levels of growth were linked to strategic moves that resulted in the provision of innovative products and services that opened and occupied new market niches, with 
significant increases in demand. In this way, it is observed that innovation is one of the fundamental pieces of strategic planning in organizations.

According to Bagno, Leiva and Oliveira (2016) there is not one only way to state what is in fact an innovative company. They propose a diagnostic method based on different approaches which should take into account important enterprise elements such as managerial elements, diversity of innovation outcomes and their commitment to the company's general strategy.

An attempt to explain the different performance of nations in international markets may be in the relationship between innovation and exporting performance (FILIPESCU et al., 2013; ROPER; LOVE, 2002). In this sense, Zou and Stan (1998) identified several indicators, both quantitative and qualitative, for exporting performance such as Export Intensity and Innovation.

Usually innovations are related to access to new markets (FILIPESCU, 2007; KNIGHT; CAVUSGIL, 2004; ROPER; LOVE, 2002). Innovation has played a determinant part on the propensity to export and with greater impact for small and medium-sized enterprises (ROPER; LOVE, 2002).

Rapid access to new markets due to innovations can be used as a path for the partial understanding of the phenomenon of accelerated internationalization.

Research on global level companies indicates that innovation processes are considered as determinant factors for the development of exclusive products, technologically advanced and with superior performance, which allows these enterprises to achieve an appropriate positioning in the market, guaranteeing the success of their international activities. (KNIGHT; CAVUSGIL, 2004).

One of the main entrance ways into the foreign market is the strategic alliance that allows access to foreign resources for production, marketing, innovation and $\mathrm{R} \& \mathrm{D}$, research and development. These alliances include joint ventures and sole ventures.

\section{Research method}

Bibliographical research was used as theoretical basis for the elaboration of the survey. The following dimensions were chosen to create the fundamental questions:

i. Entry Strategy (AHARONI, 1966; CHENG; YU, 2008; CYRINO; BARCELLOS, 2006; ROCHA; ALMEIDA, 2006)

ii. Importance of Institutions for Export (KSHETRI, 2007; RICART et al., 2004; ROPER; LOVE, 2002)

iii. Innovation Strategy (TIDD; BESSANT; PAVITT, 2005)

iv. Competitive Differential (DUNNING, 2014; PORTER, 1986)
After an analysis of the four dimensions pointed out in the literature, the following attribute modalities were defined:

i. Factors that influence the internationalization of the company;

ii. Strategies for entry into foreign markets;

iii. Institutional mechanisms for export;

iv. Factors taken into account when selecting a foreign market;

v. Competitiveness differential for the external market;

vi. Innovation;

vii. Product Differential;

viii.Crafters in the quest for innovation to achieve their goals.

The eight modalities mentioned above were subdivided into 46 items to measure the degree of importance of the attributes and 46 items to measure the degree of performance for the same attributes. An evaluation scale of 0 to 10 points was used to assign grades, or scores, that gave a quantitative perspective of the presented factors.

The case study was exclusively directed to a food company in the candy confectionary sector in Rio Grande do Norte, Brazil, and applied a quantitative and qualitative approach. The quantitative study consisted of descriptive research, based on a survey, through the application of a questionnaire. The qualitative approach was carried out through interviews.

The candy factory, which is considered a high export intensity company, has about 400 employees, was inaugurated in March 2010 with a percentage of exports over the company's global sales of more than $70 \%$ and is aimed at the North American market. Its core business is the food sector: hard candies, chewing candies, lollipops and chewing gum.

\subsection{Data collect}

The data acquisition process was divided into two parts: a survey and a semi-structured interview. The survey, which was made available for filling in loco, was applied to executives from the top management of the company under study. Concerning the qualitative approach, five executives of the company's top management were interviewed through semi-structured interviews, composed of previously defined questions, but the respondents were free to add information or considerations regarding the subjects addressed.

\subsection{Data analysis}

In order to assess the reliability of the data, the Cronbach's Alpha statistical test was performed, which showed that all attributes studied obtained a Cronbach's 
alpha ranging from 0.86 to 0.89 . This result, according to Maroco and Garcia-Marques (2006), classifies data consistency as satisfactory in the applied questionnaire.

The quantitative approach was carried out by means of a descriptive comparison of the mean reached in each one of the attributes under study concerning to the degree of importance and performance of the attributes. Its database was built in Excel, 2010 format and, for the construction of the graphs, it was used Excel and free software R, version 2.15. The qualitative approach added information that served as a basis for the understanding of the company's reality. The discussion of the results in this work was made based only on quantitative analyzes.

\section{Results}

In this section the quantitative approach results are presented. Although the interview with the top management of the company have been carried out, it is not the proposal of this work to get into its relevance, once the content of the analyzed data presented high alignment with the specialized literature and was sufficient to describe the path followed by the studied company to reach number three position in Rio Grande do Norte export rank in 2012 (MINISTÉRIO..., 2017).

\subsection{Mean of attributes concerning to the survey}

By performing an arithmetic mean of the 8 modalities of the attributes applied in the survey, Table 1 shows the results obtained concerning to performance and importance of the attributes.

Competitiveness Differential for the External Market shows the highest importance value according to the respondents, followed by Innovation; Crafters in the Quest for Innovation to Achieve their Goals; Product Differential; Factors that Influence the Internationalization of the Company; Factors Taken into Account when Selecting a Foreign Market; Institutional Mechanisms for Export and Strategies for Entry into Foreign Markets respectively.

Figure 1 shows a graphic comparison between the average Importance and Performance of the studied attributes shown in Table 1.

It is perceived that there is an alignment of the Competitiveness Differential for the External Market attribute, considering that this modality is in the first place in terms of both importance and performance analysis. However, there is a difference between the assigned scores even in the same modality, indicating in this discrepancy the non-observance of some important issues, which represent areas of opportunities for improvement in the export process.

Crafters in the Quest for Innovation to Achieve their Goals and Product Differential take respectively the third and fourth positions in both importance and performance
Table 1. Average Importance and Performance of Studied Attributes.

\begin{tabular}{|c|l|c|c|}
\hline & \multicolumn{1}{|c|}{ Attribute Description } & Performance & Importance \\
\hline I & $\begin{array}{l}\text { Competitiveness differential } \\
\text { for the external market }\end{array}$ & 9.07 & 9.10 \\
\hline II & Innovation & 6.93 & 8.90 \\
\hline III & $\begin{array}{l}\text { Crafters in the quest for } \\
\text { innovation to achieve their } \\
\text { goals }\end{array}$ & 7.50 & 8.83 \\
\hline IV & Product Differential & 7.32 & 8.68 \\
\hline V & $\begin{array}{l}\text { Factors that influence the } \\
\text { internationalization of the } \\
\text { company }\end{array}$ & 7.60 & 8.67 \\
\hline VI & $\begin{array}{l}\text { Factors taken into account } \\
\text { when selecting a foreign } \\
\text { market }\end{array}$ & 7.23 & 8.07 \\
\hline VII & $\begin{array}{l}\text { Institutional mechanisms } \\
\text { for export }\end{array}$ & 5.56 & 7.16 \\
\hline VIII & $\begin{array}{l}\text { Strategies for entry into } \\
\text { foreign markets }\end{array}$ & 2.80 & 5.60 \\
\hline
\end{tabular}

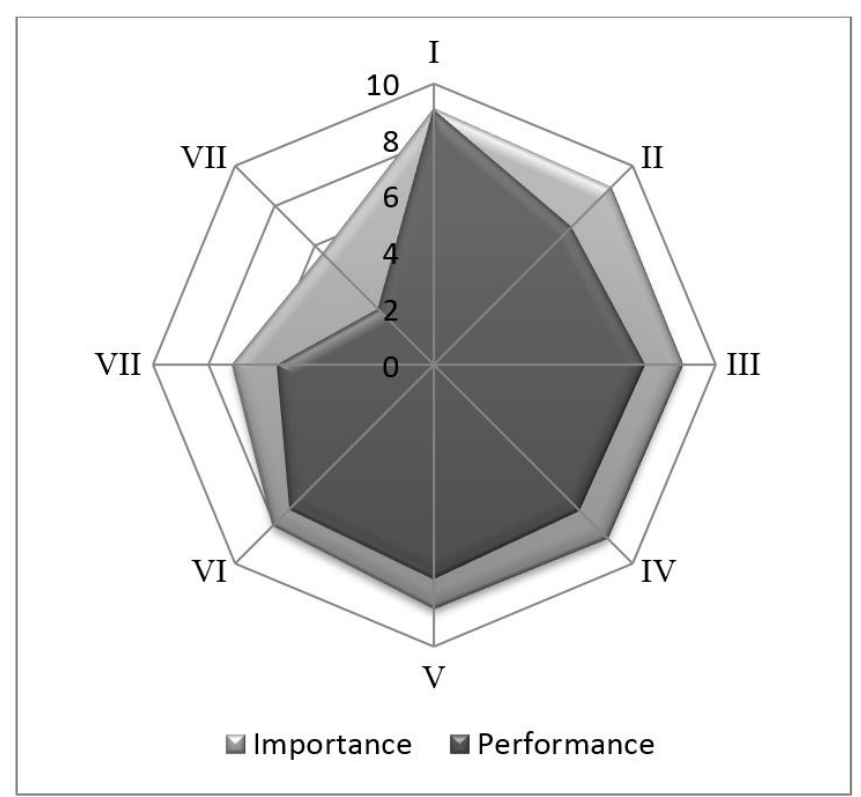

Figure 1. Comparison between the average Importance and Performance of the studied attributes.

queries, showing, once again, alignment between the thoughts of the interviewees and their execution in practice. They also present a difference between the degree of importance and the degree of performance, offering improvement areas for these modalities too.

Attribute VI, Factors taken into account when selecting a foreign market, gained a position in the responses related to the performance in detriment to the importance, due to the relevance that the individual expertise of the entrepreneurs represented in the process of internationalization of the company, also in detriment of the Innovation modality, mostly due to the short life of the company. 
The two last attributes, Institutional Mechanisms for Export - attribute VII and Strategies for Entry into Foreign Markets - attribute VIII, reached the same positions in both, importance and performance, approaches. However the scores assigned to the questions show that the company still does not use all the mechanisms available in the government institutions responsible for the development of exports, which the company's top management consider important and has not yet taken advantage of new practices to explore other opportunities to expand their external market, except for direct export.

\subsection{Competitiveness differential for the external market}

Table 2 shows the importance and performance averages between the modalities studied in attribute I - Competitiveness Differential for the External Market.

Concerning to the fact that it is a food manufacturing company, quality of the product presented maximum importance for the evaluators in this modality. Foreign markets are extremely high quality and food safety demanders to import food products, and in this case, in addition to a product with quality of its ingredients and processes, food exporting companies should ensure maximum efficiency of their food safety management programs.

The United States of America, where the main customers of the candy confectionary plant presented in this work are located, have implemented since 2011 the Food Safety Modernization Act (FSMA), which allows pre-scheduled audits, from agents of the FDA - Food and Drug Administration, at industrial facilities beyond US borders to ensure that products entering the United States were manufactured in industrial facilities that meet all food safety requirements mandated by stringent international standards by CODEX ALIMENTARIUS.

Figure 2 compares the importance and performance averages between the modalities studied in attribute I - Competitiveness differential for the external market.

The differences between the means of importance and performance in these modalities were one of the smallest, evaluated by the respondents, and it shows to have been extremely relevant in the consolidation of the company in the international market from the outset.

\subsection{Innovation}

Table 3 shows the importance and performance averages between the modalities studied in attribute II - Innovation.

International certifications were considered important innovations and order winners, since they are not required by the Brazilian institutions and the interviewees are aware that just few other companies in the candy confectionary sector have such certifications in Brazil.
The gap between the degrees of importance and performance in these modalities' queries may be understood as a result of the short time of the company life, only four years in 2014, and points at a great improvement and

Table 2. Average Importance and Performance of Studied Modalities in Attribute I.

\begin{tabular}{|c|l|c|c|}
\hline & \multicolumn{1}{|c|}{ Modality Description } & Performance & Importance \\
\hline I & Product Quality & 10.00 & 9.80 \\
\hline II & Supply Chain & 8.80 & 9.40 \\
\hline III & Innovative Product & 9.60 & 9.40 \\
\hline IV & $\begin{array}{l}\text { Attractive Price to External } \\
\text { Market }\end{array}$ & 8.60 & 9.40 \\
\hline V & $\begin{array}{l}\text { Brazilian Commodities } \\
\text { (Sugar) }\end{array}$ & 9.00 & 9.20 \\
\hline VI & $\begin{array}{l}\text { Flexibility Inherent in } \\
\text { Brazilian Culture }\end{array}$ & 8.40 & 7.40 \\
\hline
\end{tabular}

Table 3. Average Importance and Performance of Studied Modalities in Attribute II.

\begin{tabular}{|c|l|c|c|}
\hline & \multicolumn{1}{|c|}{ Modality Description } & Performance & Importance \\
\hline I & $\begin{array}{l}\text { International Quality } \\
\text { Certifications }\end{array}$ & 7.00 & 9.60 \\
\hline II & $\begin{array}{l}\text { Innovation in Existing } \\
\text { Product }\end{array}$ & 7.60 & 9.40 \\
\hline III & $\begin{array}{l}\text { Development of New } \\
\text { Marketing Channels }\end{array}$ & 5.20 & 9.00 \\
\hline IV & $\begin{array}{l}\text { Offer of New Products or } \\
\text { Services }\end{array}$ & 9.20 & 9.00 \\
\hline V & $\begin{array}{l}\text { Innovation in Company } \\
\text { Management }\end{array}$ & 5.60 & 8.80 \\
\hline VI & New Production Technologies & 7.00 & 7.60 \\
\hline
\end{tabular}

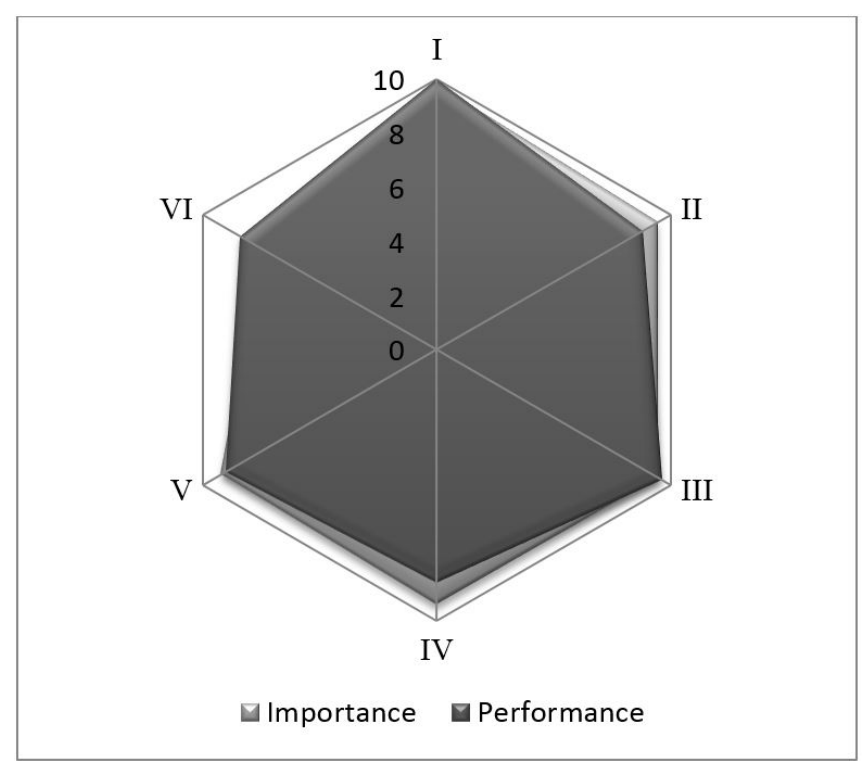

Figure 2. Average Importance and Performance of Studied Modalities in Attribute I. 
strategic opportunity area that can lead to an increase of the company's export performance.

Figure 3 shows the distances between the scores of the studied modalities in attribute II - Innovation.

\subsection{Crafters in the quest for innovation to achieve their goals}

Table 4 shows the importance and performance averages between the modalities studied in attribute III - Crafters in the Quest for Innovation to Achieve their Goals.

This section highlights the importance given to customers' feedback with suggestions for improvements, although the company does not have a high score of performance in this regard. Top management sees this modality as fundamental requirement in forming strong partnerships and strategic alliances (Figure 4).

\subsection{Product differential}

Table 5 shows the importance and performance averages between the modalities studied in attribute IV - Product Differential.

Table 4. Average Importance and Performance of Studied Modalities in Attribute III.

\begin{tabular}{|c|l|c|c|}
\hline & \multicolumn{1}{|c|}{ Modality Description } & Performance & Importance \\
\hline I & $\begin{array}{l}\text { Customer Feedback } \\
\text { with Suggestions for } \\
\text { Improvements }\end{array}$ & 6.60 & 9.60 \\
\hline II & Permanent R\&D Team & 8.20 & 9.40 \\
\hline III & $\begin{array}{l}\text { Partnerships with Suppliers } \\
\text { in the Development of New } \\
\text { Products / Technologies }\end{array}$ & 7.40 & 9.00 \\
\hline IV & $\begin{array}{l}\text { Innovation Centered } \\
\text { Partnerships }\end{array}$ & 6.60 & 8.40 \\
\hline V & $\begin{array}{l}\text { Innovation in Company } \\
\text { Management }\end{array}$ & 8.40 & 8.40 \\
\hline VI & Foreigner Trends Analysis & 7.80 & 8.20 \\
\hline
\end{tabular}

Table 5. Average Importance and Performance of Studied Modalities in Attribute IV.

\begin{tabular}{|c|l|c|c|}
\hline & \multicolumn{1}{|c|}{ Modality Description } & Performance & Importance \\
\hline I & $\begin{array}{l}\text { Customization and Private } \\
\text { Label }\end{array}$ & 8.80 & 9.60 \\
\hline & $\begin{array}{l}\text { Superior Product } \\
\text { Regarding to the } \\
\text { Competitor - New } \\
\text { Manufacturing } \\
\text { Technologies }\end{array}$ & 8.00 & 9.60 \\
\hline III & $\begin{array}{l}\text { High Acceptance Product } \\
\text { in Target Market }\end{array}$ & 9.00 & 9.40 \\
\hline IV & $\begin{array}{l}\text { Elastic Production } \\
\text { Capacity with Fast } \\
\text { Response to New Market } \\
\text { Demands }\end{array}$ & 8.00 & 9.20 \\
\hline V & $\begin{array}{l}\text { Sustainablity Centered } \\
\text { Product }\end{array}$ & 2.80 & 5.60 \\
\hline
\end{tabular}

As new factory, and still has not reached its full productive potential, the company can respond quickly to new product demands, performing well in this modality item (Figure 5).

In the view of the respondents, the products are differentiated and can be improved in several ways. Sustainability, for instance, that presents itself as a great opportunity for improvement, once it should be a concern for all kinds of enterprises that intend to grow and survive for several years in a high competitive market as the international business environment.

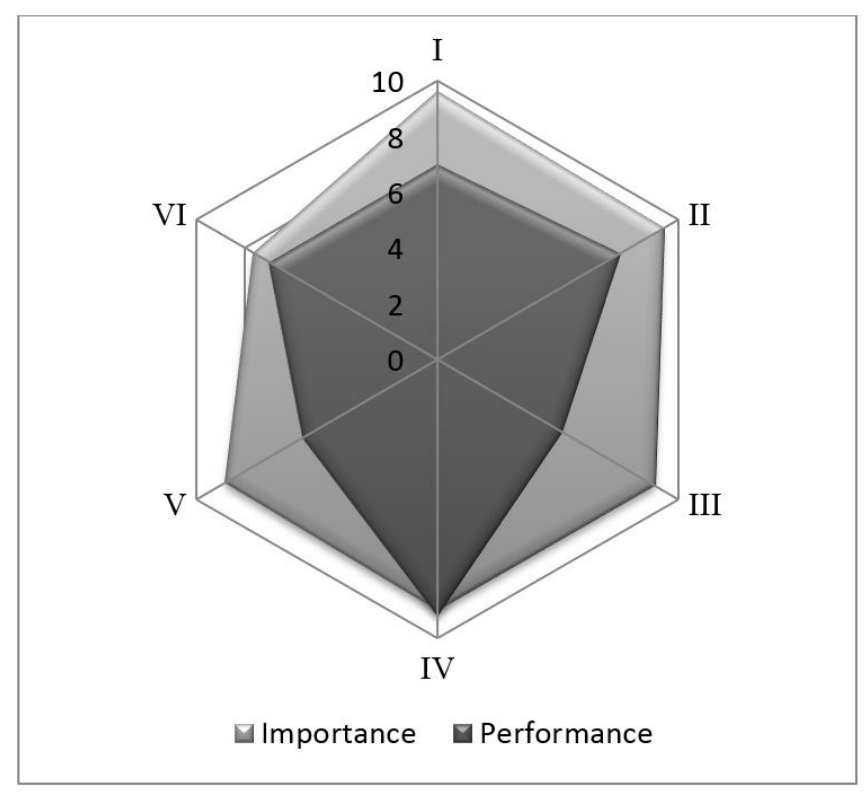

Figure 3. Average Importance and Performance of Studied Modalities in Attribute II.

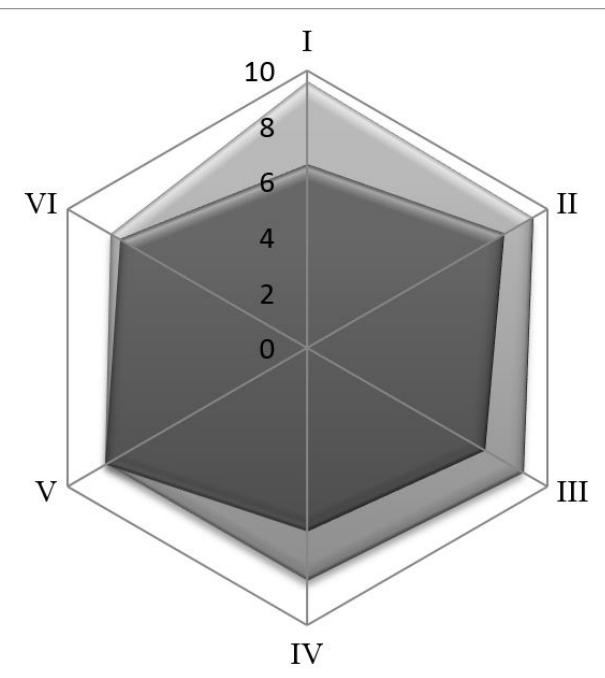

$\square$ Importance $\square$ Performance

Figure 4. Average Importance and Performance of Studied Modalities in Attribute III. 


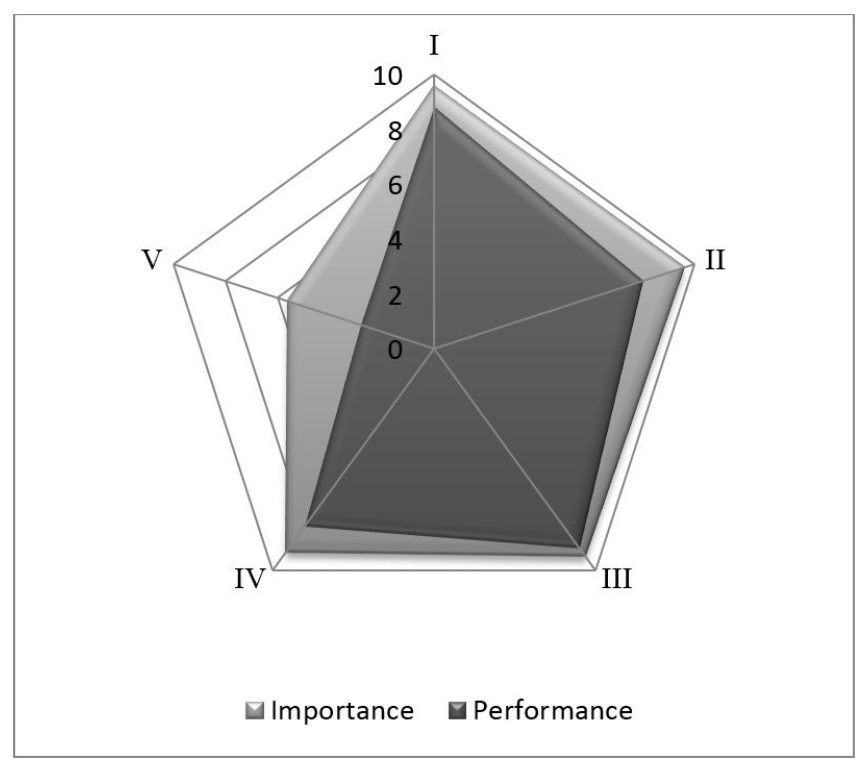

Figure 5. Average Importance and Performance of Studied Modalities in Attribute IV.

Figure 5 compares the distances between the scores of the studied modalities in attribute IV - Product Differential.

\subsection{Factors that influence the internationalization of the company}

Table 6 presents the importance and performance averages between the modalities studied in attribute $\mathrm{V}$ - Factors that Influence the Internationalization of the Company.

Regarding the critical view of the company's executives when argued about the company status as a recognized international company, a coherence between the importance given by the company and its performance to the modalities in this attribute is perceived, as shown in Figure 6.

However, it is well known that the attributes of performance are below the degree of importance, given to the requirements of this modality, which shows an opportunity of improvement for the company in a future revision of its export objectives.

\subsection{Factors taken into account when selecting a foreign market}

Table 7 brings the importance and performance averages between the modalities studied in attribute VI - Factors Taken into Account when Selecting a Foreign Market.

This modality presented one of the highest degrees of importance of the questions evaluated by the company's executives, due to their knowledge about the external market, its mechanisms, its nuances, the individual skills of top management, characteristics acquired over more than

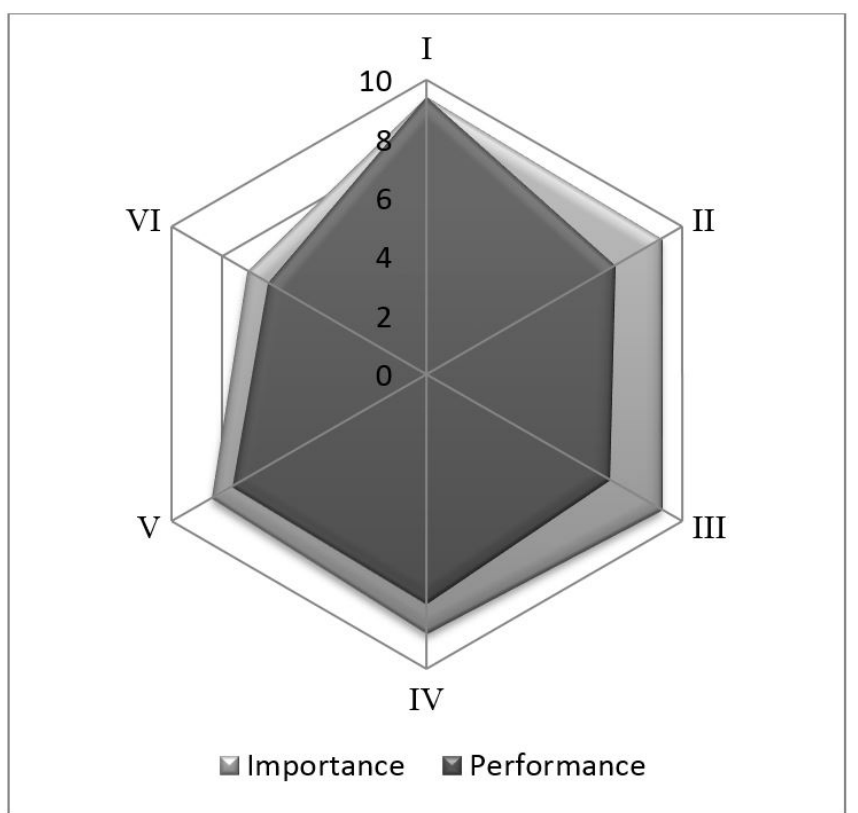

Figure 6. Average Importance and Performance of Studied Modalities in Attribute V.

Table 6. Average Importance and Performance of Studied Modalities in Attribute V.

\begin{tabular}{|l|l|c|c|}
\hline & \multicolumn{1}{|c|}{ Modality Description } & Performance & Importance \\
\hline I & $\begin{array}{l}\text { Recognized International } \\
\text { Status of the Company }\end{array}$ & 9.40 & 9.40 \\
\hline II & $\begin{array}{l}\text { Foreigner Customers } \\
\text { Demand }\end{array}$ & 7.40 & 9.20 \\
\hline III & Market Expansion & 7.20 & 9.20 \\
\hline IV & Business Opportunity & 7.80 & 8.80 \\
\hline V & $\begin{array}{l}\text { Follow Partners/ } \\
\text { Competitors in International } \\
\text { Market Expansion }\end{array}$ & 7.60 & 8.40 \\
\hline VI & $\begin{array}{l}\text { Opportunity to access } \\
\text { particular resources abroad }\end{array}$ & 6.20 & 7.00 \\
\hline
\end{tabular}

Table 7. Average Importance and Performance of Studied Modalities in Attribute VI.

\begin{tabular}{|l|l|c|c|}
\hline & \multicolumn{1}{|c|}{ Modality Description } & Performance & Importance \\
\hline I & $\begin{array}{l}\text { National or International } \\
\text { Partnerships (Existing or } \\
\text { Future) }\end{array}$ & 9.60 & 9.60 \\
\hline II & Professional Expertise & 9.40 & 9.60 \\
\hline III & Market Strategy & 8.00 & 9.20 \\
\hline IV & Personal Expertise & 9.00 & 9.00 \\
\hline V & Be a Pioneer in New Markets & 3.00 & 6.40 \\
\hline VI & $\begin{array}{l}\text { Similarity to Brazilian } \\
\text { Culture (Psychic Distance) }\end{array}$ & 4.40 & 4.60 \\
\hline
\end{tabular}

thirty years operating in this sector, together with a profitable partnership with the importing agents.

Figure 7 highlights that, although it is considered important to be a pioneer in new markets, the company has not yet used this strategy to expand its external market. 
Per the interviewees perspectives, the similarities with the Brazilian culture (psychic distance) do not have much relevance in the orders winning items and assigned similar degrees in both performance and importance evaluations.

\subsection{Institutional mechanisms for export}

Bringing the importance and performance averages between the modalities studied in attribute VII - Institutional Mechanisms for Export, Table 8 is presented.

This attribute mainly concerns to institutions existing financing lines, such as $A C C$ (Advance of Pre-Contracted Exchange) and $A C E$ (Advance of Post-Contracted Exchange) available to exporting agents. Through DRAWBACK, for instance, the exporting companies can buy subsidized raw materials to produce their goods that will be directed to the foreign market, which may represent a cost competitive advantage compared to other international players.

Despite of being considered a relevant issue, support from APEX - the Brazilian Agency for the Promotion of

Table 8. Average Importance and Performance of Studied Modalities in Attribute VII.

\begin{tabular}{|c|l|c|c|}
\hline & \multicolumn{1}{|c|}{ Modality Description } & Performance & Importance \\
\hline I & $\begin{array}{l}\text { PROEX, DRAWBACK, } A C C, \\
A C E\end{array}$ & 9.40 & 8.60 \\
\hline II & Participation in APEX Projects & 4.60 & 7.20 \\
\hline III & $\begin{array}{l}\text { Productive Development } \\
\text { Politics (MDIC) }\end{array}$ & 4.60 & 7.20 \\
\hline IV & $\begin{array}{l}\text { Participation in Government } \\
\text { Business Missions }\end{array}$ & 5.40 & 6.80 \\
\hline V & $\begin{array}{l}\text { Use of Government Studies } \\
\text { about Foreign Markets }\end{array}$ & 3.80 & 6.00 \\
\hline
\end{tabular}

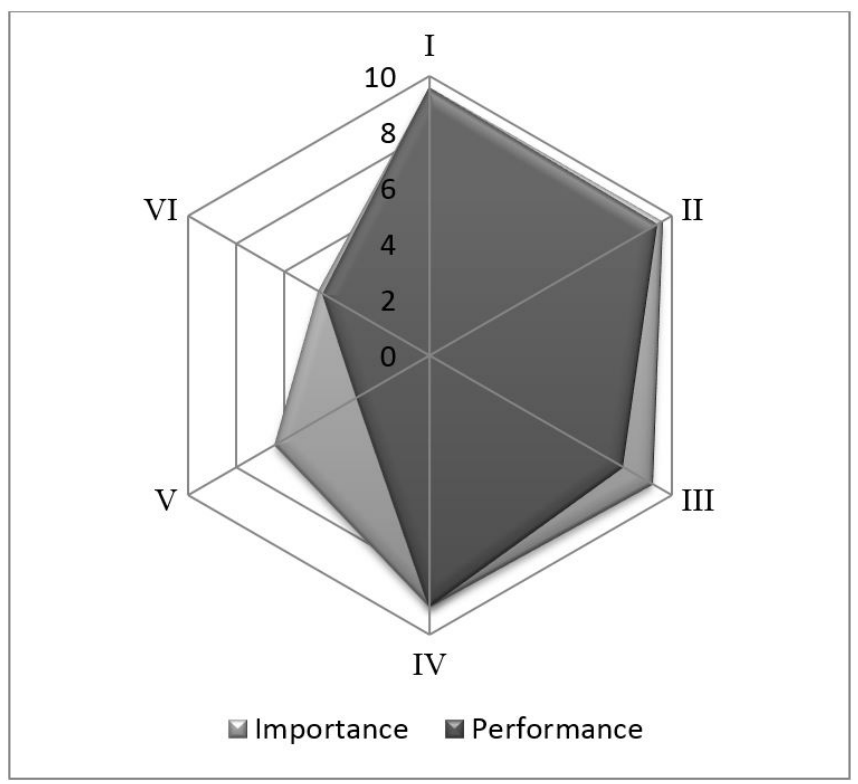

Figure 7. Average Importance and Performance of Studied Modalities in Attribute VI.
Exports and Investments and the Ministry of Development, Industry and Foreign Trade (MDIC) did not play a decisive role in the export performance of the candy factory studied.

Shown in Figure 8, the case study suggests a gap between the degree of importance and the performance of the evaluated items. Using institutional resources is not a simple task and requires deep knowledge of the bureaucratic mechanisms that permeate these facilitating devices. It can often represent success or failure in the export venture. It also requires the ability of the stakeholders to deal with public administration, to create opportunities for participation in government missions, studies etc.

\subsection{Strategies for entry into foreign markets}

Table 9 shows the importance and performance averages between the modalities studied in attribute VIII - Strategies For Entry Into Foreign Markets.

According to the respondents, direct export is considered the main strategic factor for the success of a company that

Table 9. Average Importance and Performance of Studied Modalities in Attribute IX.

\begin{tabular}{|c|l|c|c|}
\hline & Modality Description & Performance & Importance \\
\hline I & Direct Export & 9.40 & 8.60 \\
\hline II & Export Using Brokers & 2.20 & 6.80 \\
\hline III & Join Ventures & 1.60 & 5.40 \\
\hline IV & $\begin{array}{l}\text { Franchising and } \\
\text { Licences }\end{array}$ & 1.40 & 5.20 \\
\hline V & $\begin{array}{l}\text { Aquisition of Foreign } \\
\text { Companies Abroad }\end{array}$ & 1.00 & 3.40 \\
\hline VI & $\begin{array}{l}\text { New Plant Abroad } \\
\text { (Greenfield) }\end{array}$ & 1.00 & 3.20 \\
\hline
\end{tabular}

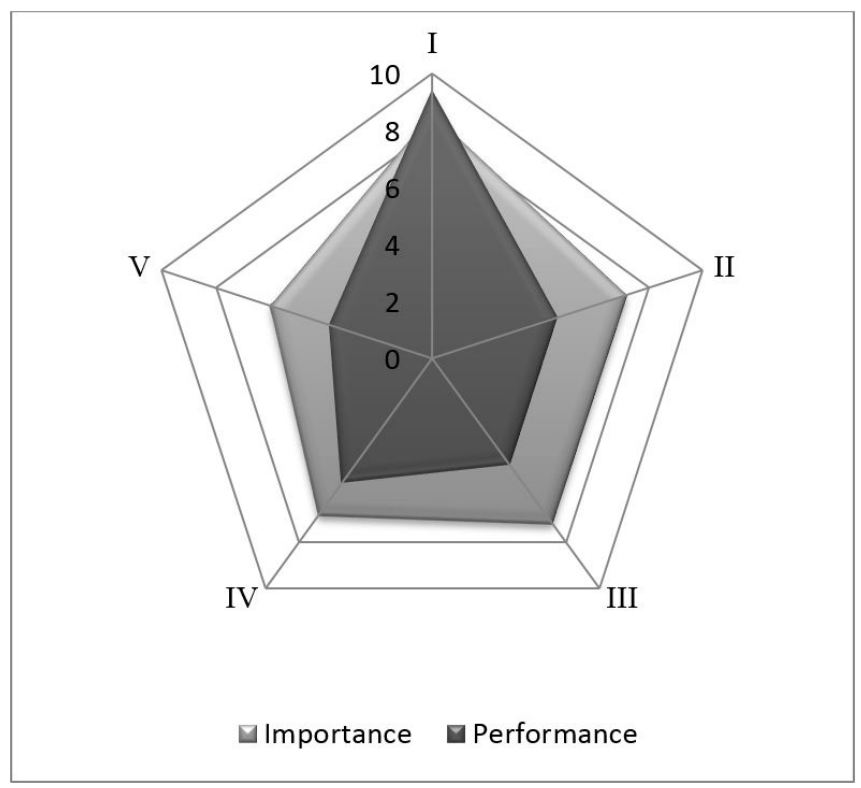

Figure 8. Average Importance and Performance of Studied Modalities in Attribute VII. 


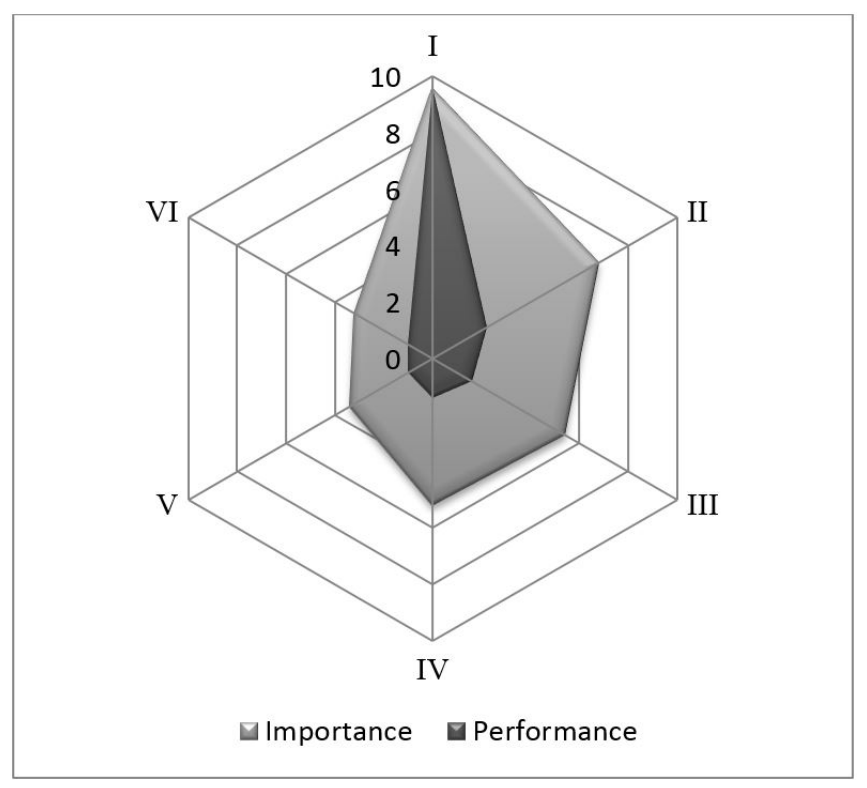

Figure 9. Average Importance and Performance of Studied Modalities in Attribute VIII.

aims to export candies in Brazil. Therefore, the performance of the company was aligned with the importance given in this regard, as shown in Figure 9.

The other strategies were not considered so relevants by the company's top management since, although they had already tried other strategies such as Franchising and Licenses and Join Ventures, they did not achieve the same success obtained by Direct Export. However, it is noticed that there is a trend to use other internationalization strategies by the interviewees, even though these alternative options are not included in the company's export planning.

\section{Conclusion}

Regarding to what has been shown so far, it is evident, for both governments and companies, the importance of international trade what also evidences a consensus between them which represents a competitive advantage for the economy as a whole.

Based on the bibliographical research, it was verified that there is a nexus between innovation, strategy and internationalization. Many authors have already proposed different forms of interaction between these elements, although they present these connections in different ways, depending on the country, type of company and even the economic and social political moment of the origin or destination of the internationalization process.

The quantitative analysis allows identifying a gap between the degrees of importance and performance present in most of the studied attributes. In addition, it was possible to perceive that, in most cases, the degrees of importance were superior to the degrees of performance, which shows the necessity of a more robust strategic planning, in order to contemplate other critical dimensions also responsible for the company success in the international market environment. Another important assertion comes from the evidences that innovation is one of the support pillars for enterprise export performance growth, in a general and sustainable way.

The present study confirmed the existence of a strong relationship between innovation, strategy and exporting performance. The quantitative analyzes strongly raise at an assertion that innovation and the other fundamental elements for internationalization, such as the competitiveness differential for the external market, must be in close harmony with the internationalization strategies so that companies can finally achieve a mature and efficient export policy.

\section{References}

AHARONI, Y. The foreign investment decision process. Thunderbird International Business Review, v. 8, n. 4, 1966.

BAGNO, R. B.; LEIVA, T. L.; OLIVEIRA, L. G. H. Innovation management: lessons learned from innovation diagnostic tools. Product: Management \& Development, v. 14, n. 1, p. 12-21, 2016.

CHENG, H.-L.; YU, C.-M. J. Institutional pressures and initiation of internationalization: Evidence from Taiwanese small-and medium-sized enterprises. International Business Review, v. 17, n. 3, p. 331-348, 2008.

CYRINO, A. B.; BARCELlOS, E. P. Estratégias de internacionalização: evidências e reflexões sobre as empresas brasileiras. In: In TANURE, B.; DUARTE, R. G. (Orgs.). Gestão internacional. São Paulo: Saraiva, 2006. p. 221-246.

DUNNING, J. H. The globalization of business (routledge revivals): the challenge of the 1990s. Abingdon-on-Thames: Routledge, 2014.

FILIPESCU, D. A. et al. Technological innovation and exports: Unpacking their reciprocal causality. Journal of International Marketing, v. 21, n. 1, p. 23-38, 2013.

FILIPESCU, D. A. Innovation and internationalization: a focus on exporting firms. Tese (Doutorado) - Universitat Autonòma de Barcelona, Barcelona, 2007.

JOHANSON, J.; VAHLNE, J.-E. The internationalization process of the firm-a model of knowledge development and increasing foreign market commitments. Journal of International Business Studies, v. 8, n. 1, p. 23-32, 1977.

JOHANSON, J.; VAHLNE, J.-E. Markets as networks: implications for strategy-making. Journal of the Academy of Marketing Science, v. 39, n. 4, p. 484-491, 2011. 
JOHANSON, J.; VAHLNE, J.-E. The Uppsala internationalization process model revisited: from liability of foreignness to liability of outsidership. Journal of International Business Studies, v. 40, n. 9, p. 1411-1431, 2009.

KIM, W. C.; MAUBORGNE, R. Blue ocean strategy: from theory to practice. California Management Review, v. 47, n. 3, p. 105-121, 2005.

KNIGHT, G. A.; CAVUSGIL, S. T. Innovation, organizational capabilities, and the born-global firm. Journal of International Business Studies, v. 35, n. 2, p. 124-141, 2004.

KSHETRI, N. Institutional factors affecting offshore business process and information technology outsourcing. Journal of International Management, v. 13, n. 1, p. 38-56, 2007.

MAROCO, J.; GARCIA-MARQUES, T. Qual a fiabilidade do alfa de Cronbach? Questões antigas e soluções modernas? Laboratório de Psicologia, v. 4, n. 1, p. 65-90, 2006.

MATHEWS, J. A.; ZANDER, I. The international entrepreneurial dynamics of accelerated internationalisation. Journal of International Business Studies, v. 38, n. 3, p. 387-403, 2007.

MINISTÉRIO DO DESENVOLVIMENTO - MDIC. Empresas exportadoras 2001 a 2016 (por faixa de valor exportado). 2017. Disponível em: <http://www. mdic.gov.br/index.php/comercio-exterior/estatisticas-decomercio-exterior/empresas-brasileiras-exportadoras-eimportadoras>. Acesso em: 01 jan. 2017.
MOEN, Ø.; GAVLEN, M.; ENDRESEN, I. Internationalization of small, computer software firms: Entry forms and market selection. European Journal of Marketing, v. 38, n. 9-10, p. 1236-1251, 2004.

PORTER, M. E. Competition in global industries. Boston: Harvard Business Press, 1986.

RICART, J. E. et al. New frontiers in international strategy. Journal of International Business Studies, v. 35, n. 3, p. 175-200, 2004.

ROCHA, A.; ALMEIDA, V. Estratégias de entrada e de operação em mercados internacionais. In: In TANURE, B.; DUARTE, R. G. (Orgs.). Gestão internacional. São Paulo: Saraiva, 2006. p. 7-37.

ROPER, S.; LOVE, J. H. Innovation and export performance: evidence from the UK and German manufacturing plants. Research Policy, v. 31, n. 7, p. 1087-1102, 2002.

TIDD, J.; BESSANT, J.; PAVITT, K. Managing innovation integrating technological, market and organizational change. New Jersey: John Wiley and Sons Ltd., 2005.

WEERAWARDENA, J. et al. Conceptualizing accelerated internationalization in the born global firm: A dynamic capabilities perspective. Journal of World Business, v. 42, n. 3, p. 294-306, 2007.

ZOU, S.; STAN, S. The determinants of export performance: a review of the empirical literature between 1987 and 1997. International Marketing Review, v. 15, n. 5, p. 333-356, 1998. 